\title{
EXPORTS AS AN INDICATOR ON OR PROMOTER OF SUCCESSFUL SWEDISH MANUFACTURING FIRMS IN THE 1990S*
}

\author{
by \\ Pär Hansson ${ }^{\psi}$ \\ and \\ Nan Nan Lundin ${ }^{\text {K }}$
}

\begin{abstract}
We study the link between exporting and productivity at the firm level. Like in previous studies we get support for that more productive firms self-select into the export market. In addition, and contrary to many of the former studies, we also obtain evidence for that exporting further increases firm productivity. Exporting firms appear to have significantly higher productivity than nonexporting. Moreover, exporters - mainly firms that increase their export intensities - have higher output growth than non-exporters. Reallocation of resources between firms may then have contributed to overall manufacturing productivity growth. Hence, we try to quantify the importance of reallocation.
\end{abstract}

JEL classification: F10, D24

Keywords: Exports, productivity, reallocation, decomposition

\footnotetext{
* We have benefited from valuable comments by Kerstin Berglöf, Andrew Bernard, Sten Johansson, Lars Lundberg and participants at the conference "International Competition, Technical Progress and Productivity" in Örebro and in seminars at FIEF and Umeå University. Financial support from Jan Wallander's and Tom Hedelius' Foundation is gratefully acknowledged.

$\psi$ Trade Union Institute for Economic Research.

ж Örebro University and Trade Union Institute for Economic Research.
} 


\section{Introduction}

A common opinion, particularly in small open economies such as Sweden, is that exports, and international trade in general, favors growth and productivity. Less well understood are the links between exporting and productivity. Empirical studies using aggregate cross-country or cross-industry data have by now been carried out to quite a large extent. ${ }^{1}$ Yet there are several problems with the interpretation of the results from these studies. First, aggregate analyses leave plenty of room for many potential explanations of an established relationship, although at the same time there is a risk that the use of aggregate data blurs correlations. Second, as in most empirical studies, problems with the direction of causality prevail. The positive relationship often detected between trade intensity (or other measures of openness) and GDP per capita may not necessarily be the result of an impact of trade (openness) on productivity. Rather, high-income countries tend for other reasons to be more open internationally.

This paper draws heavily on a burgeoning literature examining the relationship between exporting and productivity at the microeconomic level - the firm or the plant level. Substantial evidence from different countries imply that exporters have higher productivity than non-exporters within the same industry controlling for other factors affecting productivity. However, such

${ }^{1}$ See, e.g. Frankel \& Romer (1999) and Cameron, Proudman \& Readding (2000). 
cross-section type of regressions cannot reveal the exact relationship between exporting and firm productivity. High productivity firms may self-select into the export market; only successful firms can afford the additional cost that selling in a foreign market involves. On the other hand, exports may boost firms' productivity. Serving a larger market gives an opportunity to exploit firm-level economies of scale or increase specialization within the firm, for instance, by outsourcing the less productive parts. It has also been argued that learning from exporting would enhance firm productivity. Presence in the export market means greater exposure to best practice and learning from foreign buyers and competitors.

Our analysis is carried out on a panel of Swedish manufacturing firms in the 1990s. With panel data we are able to address the causality between exporting and firm productivity. Up to now there have appeared quite a number of studies on less-developed countries. ${ }^{2}$ Only a few deal with advanced economies. Particularly scarce are studies of advanced economies with large export markets. ${ }^{3}$ Unlike several of the previous studies, firms rather than plants are the objects of study since export data by plants are unavailable. Swedish data for the 1990 s is interesting to analyze

\footnotetext{
2 Aw \& Hwang (1995) Taiwan, Aw, Chung \& Roberts (1998) Taiwan and South Korea, Clerides, Lach \& Tybout (1998) Colombia, Mexico and Morocco, and Liu, Tsou \& Hammit (1999) Taiwan.

${ }^{3}$ Andrew Bernard and Bradford Jensen have accomplished several analyses on US manufacturing, e.g. Bernard \& Jensen (1999) and (2001). We are aware of two studies on advanced economies with large export intensities: Bernard \& Wagner (1997) on Germany and Girma et.al. (2002) on the UK. However, the latter employs a rather different methodology.
} 
because it is a period with a drastic increase in the export intensity - exports share of total shipment. Lower transportation and communication costs might explain the higher export intensity. Moreover, in the 1990s the EU's internal market is launched.

To preview our results, like in former studies, we find support for the hypothesis that more productive firms self-select into the export market. In addition, and contrary to many of the previous studies, we also obtain evidence for the additional hypothesis that exporting further increases firm productivity. One could easily imagine that exporting is a more important way for Swedish firms to exploit firm level economies of scale than for firms in big countries, like the US, with their large domestic markets. Technological changes have facilitated fragmentation of production across different locations (countries) and this in combination with reductions in the cost of moving goods between countries, may have led to increased specialization within the firms (vertical specialization). ${ }^{4}$ The large amount of multi-plant firms in our sample indicates that, potentially, increased specialization within the firms (outsourcing) could have been an influential factor behind enhanced firm productivity. ${ }^{5}$

Our study also relates to some newly developed general equilibrium trade models. In contrast to existing trade theories

\footnotetext{
${ }^{4}$ Hummels et.al. (2001) document that the use of imported inputs in the production of goods that are exported have grown significantly in many countries after 1970.

${ }^{5}$ In 1990, more than $75 \%$ of the employees were working in multi-plant firms, while in 1999 the share was slightly less than $70 \%$.
} 
these models emphasize the role of firms rather than characteristics of countries and industries. ${ }^{6}$ The existence of productivity differences between firms within industries means that firms with ex-ante superiority in productivity will be exporters, while less productive firms will produce only for the domestic market. Reductions in trade barriers increase aggregate productivity as more productive firms expand and less productive firms contract or close down. Increased exposure to trade thus leads to higher aggregate productivity owing to reallocations between firms within industries. In our empirical analysis we observe that output growth is higher among exporters - mainly firms that increase their export intensities. Since exporters appear to be more (and increasingly more) productive than non-exporters reallocation of resources between firms may have contributed to overall manufacturing productivity growth in Swedish manufacturing in the 1990s.

To quantify the importance of reallocation and the increasing export orientation we carry out decompositions of overall manufacturing productivity growth into within-firm effects and effects of reallocations between firms within industries and reallocations between industries. Reallocations between firms within industries have taken place towards more productive firms, whereas between industries resources have been shifted towards less productive industries. However, the bulk of overall productivity growth consists of within-firm productivity effects.

\footnotetext{
${ }^{6}$ See, e.g. Bernard et.al. (2002) and Melitz (2002).
} 
A more detailed picture of the relative importance of domestic and foreign shipments is given by a breakdown of the reallocation and the within-firm productivity effects into domestic and export components. This breakdown shows that productivity growth appears to be high within large exporters. Reallocations owing to growing exports turn out to have positive impact on aggregate productivity growth. Yet these effects are counteracted by reallocations in domestic shipment from high to low productivity firms.

The outline of the paper is the following. Section 2 examines the characteristics of exporters and non-exporters in Swedish manufacturing. In section 2.1, we present our data and show some descriptive statistics; in section 2.2 , we estimate productivity and wage premia for exporting firms. Section 3 deals with the causality between export and success. We look at productivity performances before and after exporting and output growth pattern in different types of firms. In section 4, we decompose overall manufacturing productivity growth into components owing to enhanced productivity within firms and reallocations between firms. Section 5 summarizes and concludes. 


\section{Exporters and exporting in Swedish manufacturing}

\subsection{Data and description}

The data come from Statistics Sweden's compilation of statistics from financial accounts of enterprises. Our dataset cover all Swedish manufacturing firms with more than 50 employees for the period 1990 to 1999 . The chosen period is the most recent period for which we can get data. Due to a change of the industrial classification system we cannot classify firms consistently into industries before 1990. All Swedish firms with more than 50 employees are incorporated in Statistics Sweden's survey, and crucially for this study, it is only for these firms sales is divided into domestic shipment and export. This means that we are able to construct a panel of Swedish manufacturing firms with more than 50 employees in the 1990s. Totally, there are 3275 unique firms in the panel and 841 firms are in there for the whole ten-year period. Each year there are between 1565 and 1820 firms. ${ }^{7}$ Our panel's share in total manufacturing employment is between 66 and 73 percent depending on the year of calculation, which is a rough indicator on its coverage. ${ }^{8}$

\footnotetext{
${ }^{7}$ Table A1 in Appendix gives more information about the panel. One limitation of our panel is that firms may disappear when the employment drops below 50 employees. They may also reappear later if the employment rises above 50 employees again.

${ }^{8}$ See Appendix Table A1. The denominator, total manufacturing employment, is based on plants, while the nominator consists of firms classified to manufacturing. This may either lead to an over- or an underestimation of our panel's share in manufacturing employment.
} 
During the 1990s the export intensity - the export to shipment ratio - has risen significantly among the studied firms. This is evident from Figure 1 that shows the development of the aggregate export intensity in Swedish manufacturing firms from 1976 to 1999. In 1976, the export share was 35 percent and in 1990 it has mounted to 42 percent. Yet over the 1980s the export intensity was almost constant, while in the 1990s export was booming. Eventually, in 1999 the export intensity has grown to 59 percent. ${ }^{9}$ In this longer perspective the degree of outward orientation appears to have increased above all in the 1990s.

Figure 1. Aggregate export intensity in Swedish manufacturing firms (> 50 employees), 1976-1999.

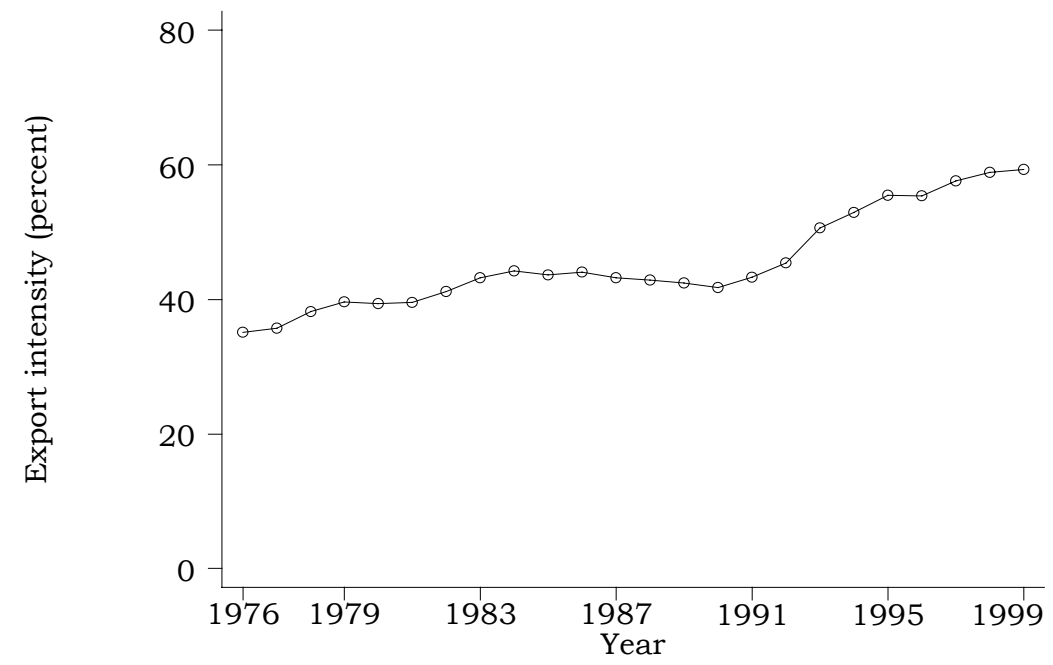

\footnotetext{
${ }^{9}$ In Appendix Table A2 we have divided the aggregate export intensity into country groups. We notice that about one-third of the production is shipped to other countries within the EU and more than 10 percent goes to other developed countries. The export intensity has grown most with other EU countries, the potential EU countries and low-income countries.
} 
In Figure 2, we show the distribution of the export intensity among the firms in the panel. The median export intensity increased from less than 15 percent 1990 to just above 30 percent 1999. 21 percent of the firms in the panel export more than half of their output 1990, while 35 percent of the firms did that 1999. In 1990, 22 percent of the firms did not export at all, and in 1999, this share has fallen to 11 percent. Thus, Swedish manufacturing firms are highly and increasingly directed towards export. In contrast to most of the former firm/plant level studies on export and productivity we are here dealing with a small advanced economy with a large, yet significantly growing, export market. 
Figure 2. The distribution of export intensities among Swedish manufacturing firms (> 50 employees), 1990 and 1999

\section{Export intensity distribution 1990}



Export intensity distribution 1999



Export intensity (percent) 
Table 1. Characteristics for exporters and non-exporters 1990 and 1999

\begin{tabular}{|c|c|c|c|c|c|c|}
\hline \multirow{2}{*}{ Variables } & \multicolumn{2}{|c|}{1990} & \multicolumn{2}{c|}{1999} \\
\cline { 2 - 6 } & Exporters & $\begin{array}{c}\text { Non- } \\
\text { exporters }\end{array}$ & $\begin{array}{c}\text { Difference } \\
\text { (t-ratio) }\end{array}$ & Exporters & $\begin{array}{c}\text { Non- } \\
\text { exporters }\end{array}$ & $\begin{array}{c}\text { Difference } \\
\text { (t-ratio) }\end{array}$ \\
\hline Employment & 351 & 162 & $188 /(3.96)$ & 318 & 156 & $162 /(2.82)$ \\
Shipment & 388 & 175 & $213 /(3.75)$ & 625 & 138 & $487 /(1.80)$ \\
Shipment/employee & 1029 & 957 & $72 /(1.53)$ & 1403 & 877 & $526 /(6.56)$ \\
Value added/employee & 307 & 286 & $21 /(2.93)$ & 424 & 273 & $151 /(7.41)$ \\
Average wage (financial) & 235 & 226 & $9 /(3.26)$ & 285 & 298 & $-13 /(-2.34)$ \\
Average wage (rams) & 141 & 136 & $5 /(3.35)$ & 185 & 182 & $3 /(1.23)$ \\
Wages: skilled (rams) & 197 & 177 & $20 /(6.99)$ & 242 & 216 & $26 /(5.07)$ \\
Wages: less-skilled (rams) & 134 & 131 & $3 /(2.35)$ & 174 & 172 & $2 /(0.80)$ \\
Capital-labor ratio & 212 & 174 & $38 /(2.97)$ & 344 & 291 & $53 /(1.44)$ \\
Skill intensity & 11 & 10 & $1 /(2.23)$ & 16 & 19 & $-3 /(-3.72)$ \\
\hline Number of firms & 1520 & 440 & & 1622 & 198 & \\
\hline
\end{tabular}

Notes: Shipment, value added and wages are in constant (1991) prices. Wages are from two different sources: the firms' financial accounts, average wage (financial) and the tax register, average wage (rams). More precisely, average wage (financial) is labor costs (including social security costs) per employee and average wage (rams) is annual earnings per employee. Wages, capital-labor ratios, value added and shipment per employee are in thousands SEK and shipment in millions SEK. Skill intensity is in percentages. The tstatistic tests the null hypothesis of equality between exporters and non-exporters. 
The Swedish firms exhibit similar characteristic differences between exporters and non-exporters as in other countries. In Table 1 we observe that exporters are substantially larger than non-exporters, both in terms of employment and shipment. They are more productive; shipment per employee and value added per employee are higher. The differences in size and productivity are in almost all cases significant. Moreover, we notice that the productivity gap between exporters and non-exporters is widening over the studied period. Exporters pay higher wages, at least for skilled workers, and they are more capital-intensive. Finally, in the beginning of the period exporters are more skill-intensive; the share of the employees with a post-secondary education is higher. Surprisingly, at the end of the period non-exporters are more skillintensive.

\subsection{Productivity (and wage) export premia}

Like in previous studies for other countries we observe apparent differences between exporters and non-exporters in Swedish manufacturing. To examine whether other firm characteristics account for the preponderance of the differences in productivity and wages we pursue a similar method as in these studies and estimate the following regressions:

$$
\begin{gathered}
\ln X_{j i t}=\alpha+\beta_{1} \text { Export }_{j t}+\beta_{2} \text { EXS }_{j t}+\lambda \text { Firm }_{j t}+ \\
+\gamma_{1} \text { Industry }_{j t}+\gamma_{2} \text { Year }_{t}+\varepsilon_{j i t}
\end{gathered}
$$


where $X_{j i t}$ is an indicator of productivity or wages of different types of workers in firm $j$ in industry $i$ at time $t$. As our main (and preferred) productivity indicator we use a standard measure of total factor productivity TFP, where physical capital, employment of skilled and less-skilled labor, and material are inputs. ${ }^{10}$ Alternatively, we employ labor productivity $V A L$ : real value added per employee. We also look at average wage $A W$, skilled labor wage $W^{s}$ and less-skilled labor wage $W^{u} \cdot{ }^{11}$ Export $_{j t}$ is a dummy for the current export status and $E X S_{j t}$ is the share of export in total shipments in firm $j$ at time $t$. Firm ${ }_{j t}$, Industry ${ }_{j t}$ and Year $_{t}$ are vectors of firm characteristics, industry and time dummies. In all specifications we use log employment as a firm control of size. The export premium $\beta_{1}$ shows the average percentage difference between exporters and non-exporters in the same industry at the same time controlling for other firm characteristics. ${ }^{12}$ The variable $E X S_{j t}$ allows for a further export premium $\beta_{2}$ that varies with export intensity.

\footnotetext{
${ }^{10}$ See Appendix 2 for a more detailed description of the calculations of TFP.

${ }^{11}$ We define skilled labor as employees with a post-secondary education, i.e. with more than 12 years of schooling. Obviously, educational attainment is not a perfect measure. For instance, it does not capture experience and it partially understates participation in further education and training. Skilled and lessskilled employment and wages are from RAMS (register based labor market statistics), Statistics Sweden

${ }^{12}$ Notice that the included firm controls in each specification here and in the rest of the paper is given in the notes below the tables presenting the results from the regressions.
} 
Table 2. Exporter productivity premia

\begin{tabular}{|c|c|c|c|}
\hline Regressors & $\begin{array}{c}(1) \\
\text { Total factor } \\
\text { productivity } \\
T F P\end{array}$ & $\begin{array}{c}(2) \\
\text { Labor } \\
\text { productivity } \\
V A L\end{array}$ & $\begin{array}{c}\text { Labor } \\
\text { productivity } \\
V A L\end{array}$ \\
\hline Export dummy & 0.063 & 0.020 & 0.026 \\
Export & {$[5.53]$} & {$[1.98]$} & {$[2.57]$} \\
& & & \\
Export share & 0.048 & 0.159 & 0.214 \\
$E X S$ & {$[4.27]$} & {$[12.32]$} & {$[16.53]$} \\
& & & \\
\hline $\bar{R}^{2}$ & 0.742 & 0.299 & 0.280 \\
Observations & 15187 & 15357 & 15357 \\
\hline
\end{tabular}

Notes: In all specifications we add log employment as a firm control of size. We include firm capital-labor ratios $\ln (K / L)$ in the labor productivity specifications. Specification (2) also contains firm skill share (share of employees with post-secondary education) $H / L$. Finally, all specifications include year dummies as well as industry (SNI92 3-digit) dummies. Square brackets [ ] give White's heteroskedasticity-consistent t-statistics.

Productivity export premia are given in Table 2. The table shows the results using both total factor productivity TFP and real value added per employee $V A L$ as the dependent variable. First, we observe, in column (1), that TFP is 6.3 percent higher in exporting firms. Also, labor productivity is significantly higher in exporting firms, as shown in column (2) and (3). In contrast to other similar studies we find that there is a positive and significant relationship between export intensity and productivity as well. ${ }^{13} \mathrm{~A}$ firm shipping 10 percent of their output abroad has a productivity advantage (TFP) of 6.8 percent over a non-exporting firm, while a

\footnotetext{
${ }^{13}$ See e.g. Aw et.al. (1998).
} 
firm that export half of its output has a productivity premia of 8.7 percent over a non-exporting firm.

Many of the previous studies have not been able to control for human capital properly. ${ }^{14} \mathrm{~A}$ comparison of the estimates in columns (2) and (3) indicates that this has probably biased their estimated exporter productivity premium upwards. Nevertheless, we should note that both the dummy for current export status Export and the coefficient on export intensity EXS continue to be significant even after we have controlled for the skill level of the workers on firm level.

Table 3. Exporter wage premia

\begin{tabular}{|c|c|c|c|c|}
\hline Regressors & $\begin{array}{c}(1) \\
\text { Average } \\
\text { wage } \\
A W\end{array}$ & $\begin{array}{c}(2) \\
\text { Average } \\
\text { wage } \\
A W\end{array}$ & $\begin{array}{c}(3) \\
\text { Skilled } \\
\text { wage } \\
W^{s}\end{array}$ & $\begin{array}{c}(4) \\
\text { Less-skilled } \\
\text { wage } \\
W^{\mu}\end{array}$ \\
\hline Export dummy & 0.009 & 0.015 & 0.068 & 0.005 \\
Export & {$[2.61]$} & {$[3.76]$} & {$[9.60]$} & {$[0.74]$} \\
Export share & 0.013 & 0.068 & 0.091 & 0.033 \\
$E X S$ & {$[3.30]$} & {$[14.73]$} & {$[11.90]$} & {$[7.50]$} \\
& & & & \\
\hline $\bar{R}^{2}$ & 0.648 & 0.542 & 0.231 & 0.522 \\
Observations & 15413 & 15413 & 15263 & 15413 \\
\hline
\end{tabular}

Notes: Like in Table 2 we add log employment as a firm control of size in all specifications. Firm capital-labor ratios $\ln (K / L)$ are included in all

\footnotetext{
${ }^{14}$ In most studies there is no control, e.g. Bernard \& Wagner (1997), Bernard \& Jensen (1999) and Liu, Tsou \& Hammit (1999), and the authors admit this shortcoming. In comparison with those cases where firm controls for human capital exist, such as the share of non-production workers in e.g. Bernard \& Jensen (1995), we believe that our classification by education is better measure.
} 
specifications as well. Moreover, specification (1) contains firm skill shares $H / L$. In all estimations there are year dummies and industry (SNI92 3-digit) dummies. Square brackets [ ] give White's heteroskedasticity-consistent t-statistics.

Wage export premia are shown in Table 3. According to column (1) average wages are significantly higher in exporting firms; the export dummy Export is significant. However, average wages in exporting firms are just slightly higher, about 1 percent. The wage differences tend to increase the more export-oriented the firms; firms that ship at least some of their output abroad tend to have somewhat higher wages. Still, wage differences are small; firms that export half of their output pay around 1.5 percent higher wages than non-exporters. Likewise for the productivity premia we see, in column (2), that it is important to control for human capital. Finally, as is evident from columns (3) and (4), the wage difference between exporters and non-exporters seems to be driven mainly by skilled labors' wages; skilled labor, in particular, appear to benefit from working in exporting firms. ${ }^{15}$

\footnotetext{
${ }^{15}$ We remark that many of our result concerning wage and productivity premia are consistent with what Bernard \& Wagner (1997) found for Germany (Lower Saxony).
} 


\section{Causality between exporting and success}

Section 2 documented that exporters in Swedish manufacturing have relatively desirable performance characteristics. One key result is that exporting firms have substantially higher productivity. However, the cross-section type of regressions in section 2 cannot reveal the exact relationship between exporting and firm performance. We will therefore shortly review some different, but not necessarily exclusive, hypotheses on how exporting and success (productivity) might be related at the firm level. We will also exploit the panel dimension in our dataset to come to grips with the direction of causality between export and success.

\subsection{Exports as an indicator of success - productivity performance before exporting}

The reasoning behind the idea that successful firms become exporters is that there exist additional costs of selling goods in foreign markets. Examples of such costs are increased transportation costs from shipping products to more distant markets, higher distributing and marketing costs arising from establishing in a new market, and extra costs associated with modifying domestic models to foreign tastes. Even though one may argue that these additional costs have declined over time, ${ }^{16}$

\footnotetext{
${ }^{16}$ E.g., falling transport and communication costs, and for Sweden and other members of the EU, the launch of EU's internal market. One intention behind the creation of the internal market is to reduce such costs. Evidently, as can be
} 
they still exist and provide entry barriers that less successful firms cannot overcome. This self-selection effect means that only producers with high productivity will enter and survive in the export market. In a sample of non-exporting firms within the same industry, the more productive firms should be more likely to become exporters.

To examine whether firms are more productive before they begin exporting we compare ex-ante productivity levels and ex-ante growth rates for exporters and non-exporters. We divide our sample into three periods: 1990-93, 1993-96, and 1996-99 and then we select those firms that did not export for three years in a row, i.e. firms that did not export in years $T-3, T-2$, and $T-1$, but may or may not have exported in year $T$. After that we regress the productivity level in year $T-3$ on the export status of the firm in year $T$.

$$
\begin{aligned}
\ln P R_{j i T-3}= & \alpha+\text { Bxport }_{j T}+\lambda \text { Firm }_{j T-3}+ \\
& +\gamma_{1} \text { Industry }_{j T-3}+\gamma_{2} \text { Year }_{T-3}+\varepsilon_{j T-3}
\end{aligned}
$$

Export $_{j T}$ equals 1 if firm $j$ is an exporter in $T(T=1993,1996$, 1999) The coefficient $\beta$ measures the productivity premium of future exporters three years before they begin to export. Alternatively, we consider the annual average productivity growth

seen in Appendix Table A2, other EU members is one of the country groups to which exports from Sweden have grown most in the 1990s. 
rates in period $t$ of future exporters in the years prior to entry, i.e. from years $T-3$ to $T$, by regressing

$$
\begin{aligned}
\Delta \ln \text { PR }_{j i t}= & \alpha+\text { BExport }_{j T}+\lambda \text { Firm }_{j T-3} \\
& +\gamma_{1} \text { Industry }_{j t}+\gamma_{2} \text { Year }_{t}+\varepsilon_{j t}
\end{aligned}
$$

Here, the coefficient $\beta$ measures the differential in productivity growth between future exporters and non-exporters. Table 4 presents the results on differences in initial productivity levels between future exporters and non-exporters. In the table the productivity performance two years prior to exporting is shown as well. ${ }^{17}$ Furthermore, Table 4 documents annual productivity growth rate premia of future exporters.

We find that future exporters both have higher TFP levels and significantly higher labor productivity two years before they enter the export market, while TFP levels and labor productivity are lower (not significant) than in future non-exporters three years before they begin exporting. Exporters ex-ante TFP growth rates are comparably, yet not significantly, higher than non-exporters. On the contrary, exporters labor productivity growth is lower (not significant). The outcome in Table 4 gives a little ambiguous, and less clear-cut support, than other similar studies to the hypothesis

\footnotetext{
${ }^{17}$ This means that we divide our sample into four groups: 1990-92, 1992-94, 1994-96, and 1996-98. After that we regress the productivity level in $T-2$ on the export status of the firm in year $T(T=1992,1994,1996,1998)$
} 
that future exporters already have a desirable productivity performance before they begin exporting. ${ }^{18}$

${ }^{18}$ See Bernard \& Wagner (1997) Table 5 and Bernard \& Jensen (1999) Table 2 and Table 3 . 
Table 4. Productivity performance prior to exporting

\begin{tabular}{|c|c|c|c|c|c|c|}
\hline \multirow{2}{*}{$\begin{array}{c}\text { Dependent } \\
\text { variable }\end{array}$} & \multicolumn{2}{|c|}{ Level $T-3$} & \multicolumn{2}{c|}{ Level $T-2$} & \multicolumn{2}{c|}{ Growth } \\
\cline { 2 - 7 } & Exporter & $\bar{R}^{2} /(\mathrm{obs})$ & Exporter & $\bar{R}^{2} /(\mathrm{obs})$ & Exporter & $\bar{R}^{2} /(\mathrm{obs})$ \\
\hline \multirow{3}{*}{$\begin{array}{c}\text { Total factor productivity } \\
T F P\end{array}$} & -0.020 & 0.677 & 0.040 & 0.707 & 0.029 & 0.214 \\
& {$[-0.41]$} & $(365)$ & {$[1.08]$} & $(649)$ & {$[1.32]$} & $(358)$ \\
Labor productivity & -0.027 & 0.351 & 0.083 & 0.402 & -0.020 & 0.152 \\
$V A L$ & {$[-0.49]$} & $(369)$ & {$[2.55]$} & $(650)$ & {$[-0.42]$} & $(363)$ \\
\hline
\end{tabular}

Notes: Period and industry (SNI92 3-digit) dummies are included in all specifications. Log employment is added as a firm control in the level specifications and firm controls in the growth specification are employment and average wage (in logs) in the beginning of the period. Moreover, the labor productivity growth specification contains change in firm capital/labor ratio $\Delta \ln (K / L)$ and change in firm skill share $\Delta(H / L)$, whereas the level specification includes $\ln (K / L)$ and $H / L$. 
Another approach to investigate whether firms that start exporting are more productive than firms that refrain from exporting even before they enter the export market is to estimate a linear probability model of exporting. ${ }^{19}$ The framework is given by

$$
\begin{aligned}
\text { Export }_{j t}= & \alpha+\beta \ln \text { PR }_{j t-1}+\delta \text { Export }_{j t-1}+\lambda \text { Firm }_{j t-1}+ \\
& +\gamma_{1} \text { Industry }_{j t}+\gamma_{2} \text { Year }_{t}+\varepsilon_{j i t}
\end{aligned}
$$

(3)

Table 5. Probability of entry in to exporting

\begin{tabular}{|c|c|}
\hline Regressors & $\begin{array}{c}\text { Linear probability } \\
\text { OLS }\end{array}$ \\
\hline Productivity $t-1$ & 0.024 \\
$\ln T F P$ & {$[3.08]$} \\
& 0.677 \\
Exporter $t-1$ & {$[57.52]$} \\
& 0.011 \\
Log employment & {$[5.23]$} \\
& 0.044 \\
Log average wage & {$[2.88]$} \\
& Yes \\
Year dummies & Yes \\
Industry dummies & 12588 \\
\hline Observations & \\
\hline
\end{tabular}

Notes: Employment and average wage are from the firms' financial accounts, i.e. average wage is labor costs per employee. We obtain more or less the same results by using register-based data on employment and average wage (annual earnings per employee) from RAMS.

\footnotetext{
${ }^{19}$ We get similar results using a probit model.
} 
Unlike other studies estimating such models, e.g. Roberts \& Tybout (1997) and Bernard \& Wagner (2001), we focus on the coefficient on the productivity level in $t-1 .^{20}$ Table 5 shows that the productivity level (TFP) is significantly higher in oneyear ahead exporters. The remaining results are also in line with what other studies have obtained, i.e. that larger firms and firms paying higher wages are more likely to become exporters and that the cost of entry into the export market, given by $\delta$ in equation (3), appears to be of similar magnitude.

\subsection{Exports as a promoter of success - productivity performance after exporting}

The preceding sections leave little doubt that exporters at any point in time have preferable performance characteristics and we get some support for the hypothesis that good firms become exporters. The latter is a question we will return to later. Nevertheless, the direction of causality may as well run from exporting to firm performance. The belief here is that exports sharpen firms' performance.

For a firm in a small open economy, such as Sweden, exports provide a very natural expansion of the market. Serving a

\footnotetext{
${ }^{20}$ The main purpose of these studies is to quantify the magnitude of the costs of entering the export market, which is given by the coefficient on whether a firm was an exporter or not in $t-1$.
} 
larger market give opportunities to take advantage of firm level economies of scale. Exports may also enhance the prospects of increased specialization within the firm, e.g. by outsourcing less productive parts either domestically or internationally. $^{21}$ Another argument, quite often put forward among business leaders and in the business press, is that firms selling in international markets are exposed to more intense competition; competition is fiercer internationally than domestically. To stay competitive those firms are forced to improve their performance. ${ }^{22} \mathrm{~A}$ third reason, perhaps more applicable on less-developed countries, is the learning-byexport argument. Firms that export are more exposed to international knowledge spillovers; they may benefits from better access to technical expertise, including both new product design and production methods, from their foreign buyers and competitors.

If exporting improves productivity at individual firms, we would expect exporting firms to have faster productivity growth than firms engaged only in the production for the domestic market. To evaluate the effects of exporting on subsequent firm performance, we regress future changes in

\footnotetext{
${ }^{21}$ The relationship between outsourcing and TFP is shown in a simple model by Feenstra \& Hanson (2001).

${ }^{22}$ This argument is hard to reconcile with an assumption of profitmaximizing firms. It is unclear why exporting firms do not chose to improve their performance before they enter the export market. Admittedly, the idea has some resemblances with the X-efficiency literature; e.g. Leibenstein (1966) and Horn et.al. (1995).
} 
productivity on the export status today and control for other initial firm characteristics.

$$
\begin{aligned}
\Delta \ln X_{j i t+1}= & \ln X_{j i t+1}-\ln X_{j i t}=\alpha+\beta \text { Export }_{j t}+\lambda \text { Firm }_{j t}+ \\
& +\gamma_{1} \text { Industry }_{j t}+\gamma_{2} \text { Year }_{t}+\varepsilon_{j i t}
\end{aligned}
$$

Here $\Delta \ln X_{j i t+1}$ is productivity growth between year $t+1$ and year $t$. Export ${ }_{j t}$ equals 1 if firm $j$ is an exporter at time $t$. As firm controls we add employment and average wage (both in $\operatorname{logs}$ ) at time $t$. Our key coefficient $\beta$ shows the difference in one year ahead productivity growth of exporters relative to non-exporters in the same industry. Table 6 shows the results.

There are no significant differences between exporters and non-exporters, either in TFP growth or in labor productivity growth, one year ahead. However, using the specification in equation (4a) means that we are mixing successful firms that continue exporting with firms that fail and exit from the export market. Analogously, for those firms that are nonexporters in the beginning of the period some may prosper and enter the export market, while other remains out of the export market over the studied period.

To take this into account we follow, e.g. Bernard \& Jensen (1999), and divide our sample of firms into four subgroups: one for firms that export both in the beginning and at the end 
of the period (exporters), one for firms that exit the export market (stoppers), one for entrants (starters), and, finally, one for firms that never export (non-exporters). ${ }^{23}$ We rerun our regression model in equation (4a) with export status dummy variables for the first three groups - Both $_{j t}$, Stop $_{j t}$, and Start $_{j t}$ - and let the set of firms that never export be our base group.

$$
\begin{aligned}
\Delta \ln X_{j i t+1}= & \alpha+\beta_{1} \text { Start }_{j t}+\beta_{2} \text { Both }_{j t}+\beta_{3} \text { Stop }_{j t}+\lambda \text { Firm }_{j t}+ \\
& +\gamma_{1} \text { Industry }_{j t}+\gamma_{2} \text { Year }_{t}+\varepsilon_{j i t}
\end{aligned}
$$

${ }^{23}$ See also Table A3 in Appendix. 
Table 6. Productivity growth after exporting (annual growth rates)

\begin{tabular}{|c|c|c|c|c|c|c|c|}
\hline $\begin{array}{l}\text { Dependent } \\
\text { variable }\end{array}$ & Exporter & $\begin{array}{c}\text { Starters } \\
(0,1)\end{array}$ & $\begin{array}{c}\text { Stoppers } \\
(1,0)\end{array}$ & $\begin{array}{l}\text { Both } \\
(1,1)\end{array}$ & $\begin{array}{l}\text { More } \\
\text { global }\end{array}$ & $\begin{array}{l}\text { Less } \\
\text { global }\end{array}$ & $\begin{array}{c}\bar{R}^{2} \\
(\mathrm{obs})\end{array}$ \\
\hline $\begin{array}{l}\text { Total factor productivity } \\
\quad \text { growth } \triangle T F P\end{array}$ & $\begin{array}{l}-0.005 \\
{[-0.59]}\end{array}$ & $\begin{array}{c}0.027 \\
{[1.44]} \\
\\
0.027 \\
{[1.44]}\end{array}$ & $\begin{array}{l}-0.025 \\
{[-1.10]} \\
-0.025 \\
{[-1.10]}\end{array}$ & $\begin{array}{l}0.004 \\
{[0.40]}\end{array}$ & $\begin{array}{c}0.004 \\
{[0.38]}\end{array}$ & $\begin{array}{c}0.004 \\
{[0.39]}\end{array}$ & $\begin{array}{c}0.156 \\
(12056) \\
\\
0.156 \\
(12056) \\
\\
0.156 \\
(12056)\end{array}$ \\
\hline
\end{tabular}

Notes: The coefficients show differences from growth rates at firms that did not export in either year. Square brackets give White's heteroskedasticity-consistent t-statistics. Year dummies and industry (SNI92 3-digit) dummies are included in all specifications. We add employment and average wage in the initial year (both in logs) as firm controls. 
Table 6. (Continued)



Notes: See above. Moreover, the labor productivity growth specifications also contain change in firm capital/labor ratio $\Delta \ln (K / L)$ and change in firm skill share $\Delta(H / L)$. 
The dummy variables assume the value of 1 if a firm is included in a group. Unlike previous studies we also take a closer look at continuing exporters $\left(\right.$ Both $\left._{i t}=1\right)$ and divide them into firms that strengthen or weaken their global commitment, i.e. increase or decrease their export intensity. The coefficients, $\beta_{1}, \beta_{2}$, and $\beta_{3}$, give the productivity growth differential for starters, continuing exporters, and stoppers relative to firms that never export during the period and Table 6 presents the results.

We observe that there are no significant differences in TFP growth between the various export groups and non-exporters. This may be explained by the fact that the TFP measure is much more sensitive to short-run variations in capacity utilization and thus contains more noise than labor productivity over a short period of time.

A more distinct, although not qualitatively different, pattern appears if we look at labor productivity. In general, continuing exporters have significantly higher labor productivity growth than non-exporters (2.1 percent). Worth noting is also that firms getting more globalised - increase their export intensities - have higher labor productivity growth than less globalised firms. ${ }^{24}$ Furthermore, and in line with previous studies, we can see that starters' labor productivity performance is better than nonexporters (4.5 percent higher and significant at 10\% level).

\footnotetext{
${ }^{24}$ The coefficients are significantly different from each other.
} 


\subsection{Productivity trajectories before and after entering (and exiting) exporting}

To examine the relationship between productivity paths and exporting in more detail we apply an approach laid out in Bernard \& Jensen (2001). ${ }^{25}$ This means that we run a regression of the form:

$$
\begin{aligned}
\ln X_{j i t}=\alpha & +\sum_{e \in E} \sum_{x \in X} \beta_{e x}\left(d_{j}^{e} \times d_{j t}^{x}\right)+\lambda \text { Firm }_{j}+ \\
& +\gamma_{1} \text { Industry }_{i}+\gamma_{2} \text { Year }_{t}+\varepsilon_{j i t}
\end{aligned}
$$

InX $X_{j i t}$, in this section, is the log level of firm productivity in firm $j$ in industry $i$ at time $t . d_{j}^{e}$ are dummy variables for the four export firm types (exporters, starters, stoppers, and non-exporters) we discussed above. In addition, there is fifth group of firms, namely those firms that switch export status more than once over the studied time period (switchers). ${ }^{26} d_{j t}^{x}$ are dummy variables showing the export status of a firm that year. For firms that start (cease) exporting we measure time relative to the transition year (period 0). Consequently, period -2 is two years before entry (exit) for starters (stoppers) and this means that two years before firm $j$ enters (exits) the export market $d_{j t}^{-2}=1$ otherwise $d_{j t}^{-2}=0$. We split our sample into two subperiods: 1990-94 and 1995-99 and in

\footnotetext{
${ }^{25}$ See also Clerides, Lach \& Tybout (1999)

${ }^{26}$ Table A3 in Appendix summarizes the export firm types and Table A4 shows that the overwhelming number of observations is for exporters. Still, there are a fair number of non-exporters and starters, while the observations for stoppers are somewhat few.
} 
each subperiod we classify the firms according to export type. We track the export behavior of starters, stoppers and switchers to detect transition years to be able to construct the $d_{j t}^{x} .^{27}$

Figure 3. Path of TFP (purged of industry and year effects)

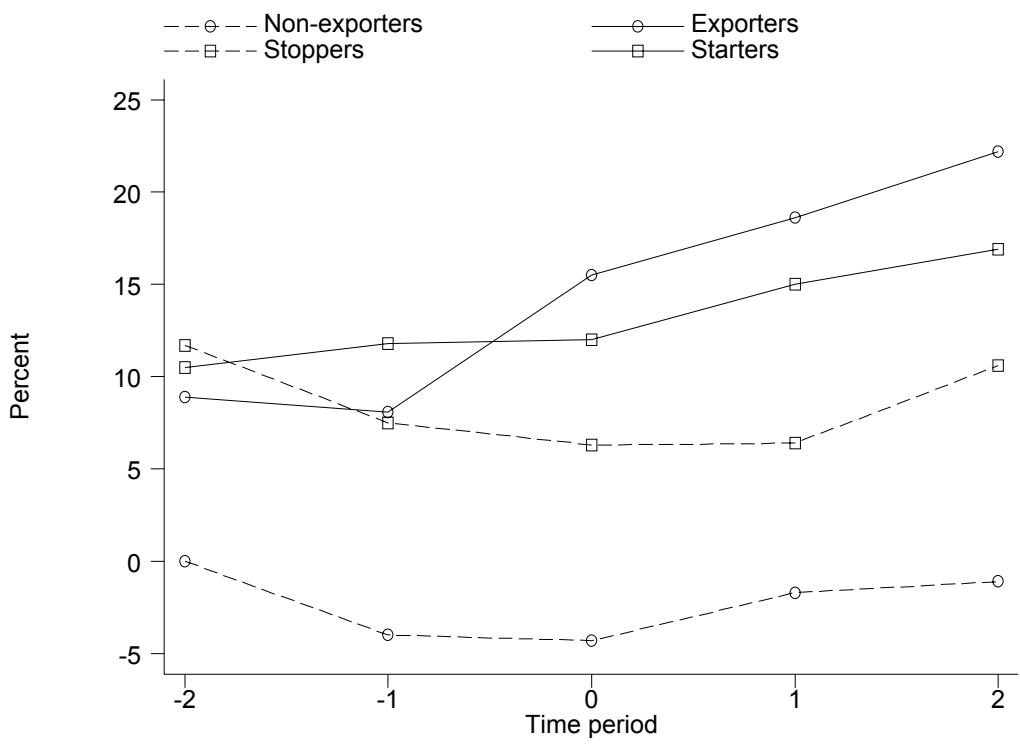

By utilizing the coefficients $\beta_{e x}$ we obtain from estimating equation (5) we can illustrate how the relative productivity levels of the different firm types develop over time. Figure 3 pictures the productivity paths of different firm types based on these

\footnotetext{
${ }^{27}$ For exporters and non-exporters we let 1990 (1995) be $d_{j t}^{-2}=1$ and 1994 (1999) be $d_{j t}^{2}=1$.
} 
coefficients. ${ }^{28}$ Since we control for industry and year effects in our regression aggregate industry and time shocks are purged from the results in the figure and the table. As our measure of productivity we use TFP. ${ }^{29}$

In Figure 3 we observe that starters even two years before the year of transition are more productive than non-exporters (10.5 percent higher TFP levels) and Table 7 shows that the difference is significant. According to Table 7 the TFP-levels of exporters and starters are significantly higher than of non-exporters at each period of time. This pattern is consistent with the hypotheses that: (i) good firms are exporters and (ii) firms that start exporting have advantageous characteristics even before they enter the export market.

Stoppers seem to perform worse compared to exporters; in the transition period 0 and afterwards exporters TFP-levels are significantly higher than stoppers, except for time period $2 .^{30}$ On the other hand, we cannot reject the hypothesis of equal TFP-levels among starters and stoppers. In many respects these results are similar to what previous studies have obtained. ${ }^{31}$

\footnotetext{
${ }^{28}$ Table A5 contains the coefficients and coefficient standard errors. To avoid clutter in the figure we merge more and less globalised firms into continuing exporters and exclude switchers.

${ }^{29}$ We get a similar pattern using labor productivity; the results can be obtained upon request.

${ }^{30}$ The reason for that is a quite large coefficient standard error of stoppers in time period 2 (see Table A5 in Appendix 3). We also notice, in Table A4 in Appendix 1, that there are relatively few observations for stoppers.

${ }^{31}$ See, e.g. Bernard \& Jensen (2001)
} 
Another interesting observation, which contrasts to most other studies, ${ }^{32}$ is that exporters and starters over time tend to improve their productivity relative to non-exporters. In fact, exporters' TFP-levels are significantly higher in the end of the time span than in the beginning, while this is not the case for starters. ${ }^{33}$ This indicates that exporting may enhance productivity and is consistent with our findings in the preceding section. ${ }^{34}$

\footnotetext{
${ }^{32}$ An exception is Aw et.al. (1998) for Taiwan.

${ }^{33}$ See notes in Table 7.

${ }^{34}$ Yet we cannot, on the basis of the estimates in Table A5 in Appendix 3, maintain that more globalised firms, i.e. firms that strengthened their commitment to the export market, perform better than less globalised firm
} 
Table 7. Differences in TFP levels between exporters, non-exporters, starters and stoppers over the time path

\begin{tabular}{|c|c|c|c|c|}
\hline $\begin{array}{c}\text { Point in } \\
\text { time }\end{array}$ & $\begin{array}{c}\text { Exporters/ } \\
\text { Non-exporters }\end{array}$ & $\begin{array}{c}\text { Starters/ } \\
\text { Non-exporters }\end{array}$ & $\begin{array}{c}\text { Exporters/ } \\
\text { Stoppers }\end{array}$ & $\begin{array}{c}\text { Starters/ } \\
\text { Stoppers }\end{array}$ \\
\hline \multirow{2}{*}{-2} & 0.089 & 0.105 & -0.028 & -0.012 \\
& $(2.18)$ & $(2.26)$ & $(-0.45)$ & $(-0.20)$ \\
-1 & 0.121 & 0.158 & 0.005 & 0.033 \\
& $(2.94)$ & $(3.54)$ & $(0.14)$ & $(1.09)$ \\
0 & 0.198 & 0.163 & 0.092 & 0.057 \\
& $(4.65)$ & $(3.32)$ & $(2.12)$ & $(1.24)$ \\
1 & 0.203 & 0.167 & 0.123 & 0.086 \\
& $(4.80)$ & $(3.51)$ & $(2.45)$ & $(1.53)$ \\
2 & 0.233 & 0.180 & 0.116 & 0.053 \\
& $(5.45)$ & $(3.64)$ & $(1.23)$ & $(0.02)$ \\
\hline
\end{tabular}

Notes: Standard errors of coefficients are corrected for that the same firm may appear in both sample sub-periods: 1990-94 and 1995-99. t-values are within parentheses. The difference in TFP-levels between exporters at the end and in the beginning of the time path $(2$ and -2$)$ is 14.4 percent and significant (t-value 2.26), whereas the corresponding difference for starters is 7.5 percent and not significant (t-value 1.09).

\subsection{Firm growth before and after entering (and exiting) exporting}

Potentially, the results above may have important implications for productivity growth on a more aggregate level (for industries and for the whole manufacturing). This is the case if it turns out that continuing exporters and entrants on the export market grow faster in terms of output and employment than non-exporters and 
stoppers. Resources would then be reallocated from firms with poor productivity paths towards firms with more favorable productivity performance (higher productivity levels and faster productivity growth).

To examine the relationship between firm growth of shipment or employment and exporting we estimate regressions of the form in equations (4a) and (4b) letting $X$ instead of productivity be shipment or employment. Table 8 shows the outcomes of these exercises.

Unlike Bernard \& Jensen (2001) the measures on firm growth (shipment growth and employment growth) are uncorrelated with initial export status. However, if we allow for differences between starters and stoppers and divide continuing exporters into more and less globalised firms some interesting patterns emerge. More globalised firms grow significantly faster in terms of shipment than less globalised firms and non-exporters (1.7-2.0 percent higher output growth). Both growth in shipment and particularly growth in employment seem to decline in stoppers relative to other firm types; employment growth is significantly lower in stoppers than in non-exporters. 
Table 8. Export status and firm growth (annual growth rates)

\begin{tabular}{|c|c|c|c|c|c|c|c|}
\hline $\begin{array}{c}\text { Dependent } \\
\text { variable }\end{array}$ & Exporter & $\begin{array}{c}\text { Starters } \\
(0,1)\end{array}$ & $\begin{array}{c}\text { Stoppers } \\
(1,0)\end{array}$ & $\begin{array}{l}\text { Both } \\
(1,1)\end{array}$ & $\begin{array}{l}\text { More } \\
\text { global }\end{array}$ & $\begin{array}{l}\text { Less } \\
\text { global }\end{array}$ & $\begin{array}{l}\bar{R}^{2} \\
(\mathrm{obs})\end{array}$ \\
\hline $\begin{array}{l}\text { Shipment } \\
\text { growth }\end{array}$ & $\begin{array}{l}0.009 \\
{[1.29]}\end{array}$ & $\begin{array}{c}0.003 \\
{[0.21]} \\
0.003 \\
{[0.24]}\end{array}$ & $\begin{array}{l}-0.028 \\
{[-1.25]} \\
-0.028 \\
{[-1.24]}\end{array}$ & $\begin{array}{l}0.012 \\
{[1.60]}\end{array}$ & $\begin{array}{c}0.020 \\
{[2.48]}\end{array}$ & $\begin{array}{c}0.003 \\
{[0.41]}\end{array}$ & $\begin{array}{c}0.090 \\
(12309) \\
\\
0.090 \\
(12309) \\
\\
0.091 \\
(12309)\end{array}$ \\
\hline
\end{tabular}

Notes: The coefficients show differences from growth rates at firms that did not export in either year. Square brackets give White's heteroskedasticity-consistent t-statistics. Year dummies and industry (SNI92 3-digit) dummies are included in all specifications. We add employment and average wage in the initial year (both in logs) as firm controls. 
Table 8. (Continued)

\begin{tabular}{|c|c|c|c|c|c|c|c|}
\hline $\begin{array}{c}\text { Dependent } \\
\text { variable }\end{array}$ & Exporter & $\begin{array}{c}\text { Starters } \\
(0,1)\end{array}$ & $\begin{array}{c}\text { Stoppers } \\
(1,0)\end{array}$ & $\begin{array}{l}\text { Both } \\
(1,1)\end{array}$ & $\begin{array}{l}\text { More } \\
\text { global }\end{array}$ & $\begin{array}{l}\text { Less } \\
\text { global }\end{array}$ & $\begin{array}{l}\bar{R}^{2} \\
(\mathrm{obs})\end{array}$ \\
\hline $\begin{array}{l}\text { Employment } \\
\text { growth }\end{array}$ & $\begin{array}{c}0.0012 \\
{[0.28]}\end{array}$ & $\begin{array}{l}-0.010 \\
{[-1.16]} \\
-0.010 \\
{[-1.15]}\end{array}$ & $\begin{array}{l}-0.031 \\
{[-2.26]} \\
-0.031 \\
{[-2.25]}\end{array}$ & $\begin{array}{l}0.001 \\
{[0.10]}\end{array}$ & $\begin{array}{c}0.004 \\
{[0.75]}\end{array}$ & $\begin{array}{c}-0.004 \\
{[-0.71]}\end{array}$ & $\begin{array}{c}0.090 \\
(12309) \\
\\
0.091 \\
(12309) \\
0.092 \\
(12309)\end{array}$ \\
\hline
\end{tabular}

Notes: See above. 


\section{Within- and between-firm decomposition of aggregate productivity growth}

In section 3 we found that exporters are more productive than nonexporters. Actually, and counter to the result in most other similar studies, the productivity gap between exporters and non-exporters has widened in Swedish manufacturing in the 1990s. This in combination with higher output growth among exporters - at least those that are getting more globalised - indicates that reallocations of resources from less to more (and increasingly more) efficient firms would have contributed to overall manufacturing productivity growth in Swedish manufacturing in the 1990s. International trade and exports, in particular, have enabled this process.

In order to quantify the importance of the increasing export orientation of Swedish manufacturing in the 1990s we carry out a decomposition of overall manufacturing productivity growth. If we only make use of continuing firms, i.e. firms that exist both in year $t$ and in year $t+1,{ }^{35}$ we can decompose changes in aggregate manufacturing productivity growth into three components: (i) the within-firm (own firm) productivity effect, (ii) the within-industry

\footnotetext{
${ }^{35}$ By doing this we ignore the impact on aggregate productivity of entry and exit of firms, which we recognize as a serious shortcoming. However, our data set is not very suitable for that purpose because the reasons why firms enter and exit from our data set may not at all be related to birth or failure of firms. One explanation to entry (exit) may simply be that employment has increased (decreased) above (below) the cut-off point of 50 employees.
} 
reallocation effect, and (iii) the between-industry reallocation effect. To show that, let us first define aggregate productivity $P R$ as

$$
\ln P R=\sum_{j=1}^{J} \theta_{j i} \ln P R_{j i}=\sum_{j=1}^{J} q_{j i} s_{i} \ln P R_{j i}
$$

where $P R_{j i}$ is the productivity level in firm $j$ in industry $i$ and $\theta_{j i}$ is the value of sales in firm $j$ in industry $i$ relative to total manufacturing sales. $\theta_{j i}$ is the product of firm $\mathrm{j}$ :s market share in industry $i, q_{j i}$, and industry i:s market share of total manufacturing, $S_{i} \cdot{ }^{36}$ A decomposition of the annual change in aggregate productivity growth is then given by

$$
\begin{gathered}
\Delta \ln P R=\sum_{j=1}^{J} \bar{\theta}_{j i} \Delta \ln P R_{j i}+\sum_{j=1}^{J} \ln \bar{P}_{j i} \Delta \theta_{j i}= \\
\sum_{j=1}^{J} \bar{s}_{i} \bar{q}_{j i} \Delta \ln P R_{j i}+\sum_{j=1}^{J} \bar{s}_{i} \ln \bar{P} \bar{R}_{j i} \Delta q_{j i}+\sum_{j=1}^{J} \bar{q}_{j i} \ln \bar{P} \bar{R}_{j i} \Delta s_{i}
\end{gathered}
$$

The first component is the own firm productivity effect; this rises if the market share weighted average of individual firm's productivity growth increases. The second component is the effect of reallocations of market shares among firms within industries. The third component is the outcome from reallocations between industries.

${ }^{36} \theta_{j i}=Q_{j i} / Q=\left(Q_{j i} / Q_{i}\right)\left(Q_{i} / Q\right)=q_{j i} s_{i}$ where $Q_{j i}$ is the value of sales in firm $j$ in industry $i, Q_{i}$ is sales value in industry $i$, and $Q$ is total manufacturing sales. 
Table 9 shows the result of our decomposition of annual average aggregate productivity growth for continuing firms in Swedish manufacturing between 1990 and 1999. We obtain our figures by calculating the components in equation (7) for each pair of years in the period and then take average across the years. We use both TFP and labor productivity as productivity measures.

Overall, TFP at continuing manufacturing firms grew at an average of 3.4 percent per annum from 1990 to 1999, while the labor productivity growth was 6.9 percent per annum. As in several other studies, and irrespective of whether productivity is measured by TFP or by labor productivity, the within-firm (own firm) productivity effect makes up the bulk of overall productivity growth. The total effect of reallocation, i.e. the sum of withinindustry and between-industry reallocation, is negative for TFP growth and positive for labor productivity growth. Yet the withinindustry reallocation effect is always positive and for labor productivity growth fairly important.

One interpretation of the result in Table 9 is that within industries resources have been reallocated towards more productive firms, while between industries resources have been shifted towards less productive industries. Another conclusion we can draw from Table 9 is that the impact on aggregate productivity growth of reallocations between firms within industries has at least been as important (in absolute terms) as the influence of reallocations between industries. 
Table 9. Decomposition of aggregate productivity growth in Swedish manufacturing, 1990-99

\begin{tabular}{|c|c|c|c|c|c|}
\hline $\begin{array}{c}\text { Productivity } \\
\text { measure }\end{array}$ & Overall & $\begin{array}{c}\text { Within- } \\
\text { firm } \\
\text { (own) effect }\end{array}$ & $\begin{array}{c}\text { Within- } \\
\text { industry } \\
\text { reallocation }\end{array}$ & $\begin{array}{c}\text { Between- } \\
\text { industry } \\
\text { reallocation }\end{array}$ & $\begin{array}{c}\text { Total } \\
\text { effect of } \\
\text { reallocation }\end{array}$ \\
\hline TFP growth & 0.034 & $\begin{array}{c}0.056 \\
(165 \%)\end{array}$ & $\begin{array}{l}0.011 \\
(32 \%)\end{array}$ & $\begin{array}{l}-0.033 \\
(-97 \%)\end{array}$ & $\begin{array}{l}-0.022 \\
(-65 \%)\end{array}$ \\
$\begin{array}{c}\text { Labor } \\
\text { productivity } \\
\text { growth }\end{array}$ & 0.069 & $\begin{array}{c}0.054 \\
(78 \%)\end{array}$ & $\begin{array}{l}0.034 \\
(49 \%)\end{array}$ & $\begin{array}{l}-0.019 \\
(-27 \%)\end{array}$ & $\begin{array}{c}0.015 \\
(22 \%)\end{array}$ \\
\hline
\end{tabular}

Notes: The share of overall productivity growth is shown in parentheses.

To give a more detailed picture of the relative importance of domestic and foreign shipments we follow Bernard \& Jensen (2001) and carry out a breakdown of the reallocation and the own firm productivity effects into a domestic and an export component. This gives us an expression for the decomposition (industry index $i$ is suppressed)

$$
\begin{aligned}
\Delta \ln P R= & \sum_{j=1}^{J} \bar{\theta}_{j}^{D} \Delta \ln P R_{j}+\sum_{j=1}^{J} \bar{\theta}_{j}^{X} \Delta \ln P R_{j}+ \\
& +\sum_{j=1}^{J} \ln \bar{P}_{R_{j}} \Delta \theta_{j}^{D}+\sum_{j=1}^{J} \ln \bar{P} \bar{R}_{j} \Delta \theta_{j}^{X}
\end{aligned}
$$

$\theta_{j}^{D}$ is firm j's domestic shipment share and $\theta_{j}^{X}$ is its export share of total manufacturing output. ${ }^{37}$ An implicit assumption here is

\footnotetext{
37 We can divide total output into domestic shipment $D$ and export $X$, i.e. $Q=D+X$, involving that $\theta_{j}=\theta_{j}^{D}+\theta_{j}^{X}$.
} 
that productivity levels are the same within firms for both types of shipments. Table 10 shows the result of the decomposition.

Table 10. Contribution of exports to the reallocation and the within-firm (own) effects

\begin{tabular}{|c|c|c|c|c|c|}
\hline \multirow{2}{*}{$\begin{array}{c}\text { Productivity } \\
\text { measure }\end{array}$} & Overall & \multicolumn{2}{|c|}{$\begin{array}{c}\text { Within-firm (own) } \\
\text { effect }\end{array}$} & \multicolumn{2}{c|}{$\begin{array}{c}\text { Total effect of } \\
\text { reallocation }\end{array}$} \\
\cline { 3 - 6 } & & Domestic & Exports & Domestic & Exports \\
\hline TFP growth & 0.034 & $\begin{array}{c}0.015 \\
(44 \%)\end{array}$ & $\begin{array}{c}0.040 \\
(118 \%)\end{array}$ & $\begin{array}{c}-0.042 \\
(-123 \%)\end{array}$ & $\begin{array}{c}0.021 \\
(62 \%)\end{array}$ \\
$\begin{array}{c}\text { Labor } \\
\text { productivity } \\
\text { growth }\end{array}$ & 0.069 & $\begin{array}{c}0.016 \\
(23 \%)\end{array}$ & $\begin{array}{c}0.038 \\
(55 \%)\end{array}$ & $\begin{array}{c}-0.117 \\
(-169 \%)\end{array}$ & $\begin{array}{c}0.132 \\
(191 \%)\end{array}$ \\
\hline
\end{tabular}

We notice that productivity growth appears to be high in large exporters. This contrasts to the findings in Bernard \& Jensen (2001) where exporters seem to have relatively little impact on the own firm productivity effect. Partly, this can be explained by the fact that the export share in Swedish firms is considerably larger than in the US firms. However, another factor that may have played a role is that Swedish exporters, as we could see in Figure 3 , in the 1990s tend to improve their productivity performance relative to Swedish non-exporters. In the US, exporters are more productive than non-exporters; still the productivity gap is constant over time. $^{38}$

\footnotetext{
${ }^{38}$ See Bernard \& Jensen (2001) Figure 1.
} 
The reallocation towards growing exporters has a large positive impact on aggregate manufacturing productivity growth. However, this effect is counteracted by changes in domestic shipments, which are negatively related to firms' productivity levels. For labor productivity growth this implies that the total effect of reallocation is relatively small, and for TFP growth, the reallocation effect of changes in domestic shipments is of a magnitude leading to a negative total reallocation effect. ${ }^{39}$

In sum, the decompositions in section 4 shows that the within-firm (own firm) productivity effect, in particular in large exporting firms, has contributed to the greater part of overall manufacturing productivity growth in Swedish manufacturing in the 1990s. The reallocation effect has been of minor importance. Reallocations within industries have occurred from less productive to more productive firms, while between industries an allocation towards less productive industries appear to have taken place. Reallocations owing to growing export shipment turn out to have a positive effect on aggregate productive growth. At the same time this is counteracted by the reallocations due to changes in domestic shipments.

\footnotetext{
${ }^{39}$ Bernard \& Jensen (2001) found for the US that the total reallocation effect is positive and fairly important. Yet even in their analysis, the domestic reallocation effect is negative.
} 


\section{Summary and conclusions}

We find that Swedish exporting manufacturing firms are substantially more productive than non-exporting firms within the same industry after we have taken firm characteristics, such as factor intensities and size, into account. This is by now a wellestablished fact for several countries, developed as well as developing. In our study this finding seems to be robust even to proper control of the firm's human capital. Less well established is the positive and significant correlation we obtain between firm's export intensity and productivity. However, the large productivity difference appears to exist between exporters and non-exporters and not between firms with varying export intensities. Moreover, another interesting finding is that exporting firms tend to pay slightly, yet significantly, higher wages than non-exporting firms. Still more interesting is that skilled labor seems to benefit more from working in exporting firms than less-skilled.

As pointed out before, these cross-section types of regressions do not tell us anything about the direction of causality between exporting and firm productivity. Arguably, the direction may run both ways. Recognizing this possibility, we exploit the panel dimension in our data set by examining productivity paths of different firm types.

Consistent with the hypothesis that more productive firms selfselect into export, and in accordance with the result in most other 
similar studies, we find that firms that start exporting (starters), even two years before they begin to export, are significantly more productive than firms that never export (non-exporters). Firms that always export (exporters) and starters have significantly higher productivity levels than non-exporters. Continuing exporters perform better than stoppers. These findings resemble what other studies have obtained and an interpretation is that good firms are exporters.

Contrary to other studies, we also find that over time exporters tend to improve their productivity relative to non-exporters. This indicates that exporting has enhanced productivity in Swedish manufacturing firms in the 1990s. We have put forward various explanations to why exports may sharpen firm's performance. However, on the basis of this study we cannot distinguish the factors behind this development. To disentangle the reasons is certainly an interesting area of further research; another is whether we can observe a similar relationship between export and productivity in the less export oriented 1980s.

Our results also suggest that exporters - mainly more globally committed exporters - have higher output growth than nonexporters. This in combination with the observation that exporting firms appear to have significantly higher productivity than nonexporting firms means that reallocation of resources between firms may have contributed to overall manufacturing productivity growth in Sweden in the 1990s. To quantify the importance of 
reallocation and exports we decompose overall manufacturing productivity growth into within-firm (own firm) and reallocation effects.

We find that the bulk of overall productivity growth in the 1990s consists of own firm productivity effects. Reallocations within industries towards more productive firms have taken place, whereas between industries resources have been shifted towards less productive industries. A breakdown of the reallocation and the own firm effects into a domestic and an export component shows that productivity growth appears to be high within large exporters. Reallocations owing to growing exports turn out to have positive effect on aggregate productivity growth. Yet this is counteracted by reallocations due to changes in domestic shipments. 


\section{References}

Aw, B.Y. \& Hwang, A.R. (1995), Productivity and the export market: A firm-level analysis. Journal of Development Economics, 47, 313-332.

Aw, B.Y, Chung, S. \& Roberts, M. (1998), Productivity and the decision to export. Micro evidence from Taiwan and South Korea. NBER Working Paper no 6558.

Bernard, A, Eaton, J, Jensen, B. \& Kortum, S. (2002), Plants and productivity in international trade. Mimeo.

Bernard, A. \& Jensen, B. (1995), Exporters, jobs, and wages in U.S. manufacturing: 1976-1987. Brookings Papers on Economic Activities: Microeconomics, 67-119.

Bernard, A. \& Jensen, B. (1999), Exceptional exporter performance: cause, effect, or both? Journal of International Economics, 47, 1-25.

Bernard, A. \& Jensen, B. (2001), Exporting and productivity: The importance of reallocation. Mimeo.

Bernard, A. \& Wagner, J. (1997), Exports and success in German manufacturing. Weltwirtschaftliches Archiv, 133, 134-157.

Bernard, A. \& Wagner J, (2001), Export entry and exit by German firms. Weltwirtschaftliches Archiv, 137, 105-123.

Cameron, G, Proudman, J. \& Redding, S. (2000), Productivity growth in an open economy: the experience of the UK, in Barrell, R, Mason, G. \& O'Mahony, M. (eds), Productivity, innovation and economic performance. Cambridge: Cambridge University Press.

Clerides, S, Lach, S. \& Tybout, J. (1998), Is learning by exporting important? Micro-dynamic evidence from Colombia, Mexico, and Morocco. Quarterly Journal of Economics, 113, 903-947.

Disney, R, Haskel, J. \& Heden, Y. (2000), Restructuring and productivity growth in UK manufacturing. GLM Research Paper 2000/13.

Feenstra, R. \& Hanson, G. (2001), Global production sharing and rising inequality: A survey of trade and wages. NBER working paper no 8372.

Foster, L, Haltiwanger, J. \& Krizan C.J. (1998), Aggregate productivity growth: Lessons from microeconomic evidence. NBER working paper no 6803. 
Frankel, J. \& Romer, D. (1999), Does trade cause growth? American Economic Review, 89, 379-399.

Girma, S. Greenaway, D. \& Kneller, R. (2002), Does exporting lead to better performance? A microeconometric analysis of matched firms. GEP research paper 2002/09.

Horn, H, Lang, H. \& Lundgren, S. (1995), Managerial effort, incentives, X-inefficiencies and international trade. European Economic Review, 39, 117-138.

Hummels, D, Ishii, J. \& Yi, K-M (2001), The nature and growth of vertical specialization in world trade. Journal of International Economics, 54, 75-96.

Leibenstein, H. (1966), Allocative efficiency versus X-efficiency. American Economic Review, 392-415.

Liu, J-T, Tsou, M-W \& Hammit, J. (1999), Export activity and productivity: Evidence from the Taiwan electronics industry. Weltwirtschaftliches Archiv, 135, 675-691.

Melitz, M. (2002), The impact of trade on intra-industry reallocations and aggregate industry productivity. NBER working paper no 8881 .

Roberts, M. \& Tybout, J. (1997), The decision to export in Colombia: An empirical model of entry with sunk costs. American Economic Review, 97, 545-564. 


\section{Appendix $1 \quad$ Data description}

Table A1. Panel information

\begin{tabular}{|c|c|c|c|c|c|c|c|}
\hline \multirow{2}{*}{$\begin{array}{l}\text { Years } \\
\text { In the } \\
\text { panel }\end{array}$} & \multirow{2}{*}{$\begin{array}{c}\text { Number } \\
\text { of } \\
\text { firms }\end{array}$} & \multirow[b]{2}{*}{ Year } & \multicolumn{3}{|c|}{ Number of firms } & \multicolumn{2}{|c|}{ Employment } \\
\hline & & & \multirow{2}{*}{$\begin{array}{l}\text { Total } \\
1960 \\
\end{array}$} & \multicolumn{2}{|c|}{$\begin{array}{l}\text { Non-Exporters } \\
\text { (Percent) }\end{array}$} & \multirow{2}{*}{\begin{tabular}{|c|}
$\begin{array}{c}\text { Number } \\
\text { (Thousands) }\end{array}$ \\
605 \\
\end{tabular}} & \multirow{2}{*}{$\begin{array}{c}\begin{array}{c}\text { Share* } \\
\text { (Percent) }\end{array} \\
66.3\end{array}$} \\
\hline 10 & 841 & 1990 & & 440 & 22.5 & & \\
\hline 9 & 150 & 1991 & 1884 & 406 & 21.6 & 567 & 67.6 \\
\hline 8 & 134 & 1992 & 1730 & 361 & 20.9 & 513 & 67.8 \\
\hline 7 & 160 & 1993 & 1565 & 282 & 18.0 & 472 & 69.2 \\
\hline 6 & 178 & 1994 & 1578 & 262 & 16.6 & 498 & 69.0 \\
\hline 5 & 182 & 1995 & 1657 & 260 & 15.7 & 528 & 69.9 \\
\hline 4 & 239 & 1996 & 1731 & 274 & 15.9 & 536 & 71.3 \\
\hline 3 & 358 & 1997 & 1729 & 188 & 10.9 & 527 & 70.5 \\
\hline 2 & 462 & 1998 & 1801 & 196 & 10.9 & 543 & 70.7 \\
\hline 1 & 571 & 1999 & 1820 & 198 & 10.9 & 547 & 73.0 \\
\hline \multicolumn{2}{|c|}{$\begin{array}{l}\text { Total number of } \\
\text { firms: } 3275\end{array}$} & \multicolumn{4}{|c|}{$\begin{array}{l}\text { Total number of } \\
\text { firm-years: } 17455\end{array}$} & & \\
\hline
\end{tabular}

*Share of total manufacturing employment.

Table A2. $\quad$ Aggregate export intensity divided into country groups, 1990 and 1999 (Percent)

\begin{tabular}{|c|c|c|c|}
\hline Country groups & $\begin{array}{c}\text { Export } \\
\text { intensity } \\
1990\end{array}$ & $\begin{array}{c}\text { Export } \\
\text { intensity } \\
1999\end{array}$ & $\begin{array}{c}\Delta \text { Export } \\
\text { intensity }\end{array}$ \\
\hline EU 14 & 30.8 & 32.9 & 2.1 \\
\hline Potential EU 10 & 0.3 & 2.3 & 2.0 \\
\hline Other DC & 10.8 & 11.9 & 1.1 \\
\hline Japan and Asian NIC & 1.9 & 2.7 & 0.8 \\
\hline Low-income countries & 4.5 & 6.6 & 2.1 \\
\hline Total & 48.3 & 56.4 & 8.1 \\
\hline
\end{tabular}

Notes: The figures are based on Foreign trade statistics and Industrial statistics from Statistics Sweden and are not comparable with the figures in Figures 1 and 2.

EU 14: Austria, Belgium, Denmark, Finland, France, Germany, Greece, Ireland, Italy, Luxembourg, The Netherlands, Portugal, Spain and the United Kingdom.

Potential EU 10: Czech Republic, Estonia, Cyprus, Hungary, Latvia, Lithuania, Malta, Poland, Slovenia, and Slovakia.

Asian NIC: Hong Kong, Singapore, South Korea and Taiwan. 
Other DC: Australia, Canada, Iceland, New Zealand, Switzerland, and the US.

Low-income countries: Developing countries, Bulgaria, Mexico, Romania and Turkey.

Table A3. Firm export types

\begin{tabular}{|c|l|}
\hline Exporters $(1,1)$ & $\begin{array}{l}\text { Firms that exports in all years during the period. } \\
\text { This group can be further divided into more and } \\
\text { less } \text { globalised exporters, i.e. exporters with } \\
\text { increased (decreased) export intensities during the } \\
\text { period. } \\
\text { Firms that becomes an exporter during the period } \\
\text { (and does not reswitch) }\end{array}$ \\
Stoppers $(1,0)$ & $\begin{array}{l}\text { Firms that ceases exporting during the period } \\
\text { (and does not reswitch) }\end{array}$ \\
Fon-exporters $(0,0)$ & $\begin{array}{l}\text { Firms that never export in any year during the period } \\
\text { Firms that switches export status more than once } \\
\text { during the period }\end{array}$ \\
\hline
\end{tabular}

Table A4. Number of observations of each firm export type

\begin{tabular}{|c|c|}
\hline $\begin{array}{c}\text { Firm export } \\
\text { type }\end{array}$ & $\begin{array}{c}\text { Number of } \\
\text { observations }\end{array}$ \\
\hline Exporters & $8901(77.8 \%)$ \\
Starters & $703(6.1 \%)$ \\
Stoppers & $270(2.4 \%)$ \\
Non-exporters & $1016(8.9 \%)$ \\
Switchers & $555(4.8 \%)$ \\
\hline Total & $11445 \quad(100 \%)$ \\
\hline
\end{tabular}




\section{Appendix 2 Total factor productivity}

We calculate $(\log )$ TFP as

$\ln T F P_{j i}=\ln Y_{j i}-\alpha_{K i} \ln K_{j i}-\alpha_{S i} \ln L_{j i}^{S}-\alpha_{U i} \ln L_{j i}^{U}-\alpha_{M i} \ln M_{j i}$

where $Y$ is real gross output, $K$ real capital, $L^{S}$ and $L^{U}$ are number of skilled and less-skilled employees, and $M$ real material use (intermediates and energy), the $\alpha: s$ are shares of each factor in gross output and $j$ denotes firms and $i$ industries. $M$ is from the financial statistics and $L^{s}$ and $L^{u}$ are from RAMS (register based labor market statistics). Capital stocks are constructed using perpetual inventory methods with depreciation rates: buildings 3 percent and machinery 11 percent. We deflate output, capital and materials by the appropriate four-digit industry-digit industry price deflator. Following Foster et.al. (1998) and Disney et.al. (2000) we calculate the factor shares at the three-digit industry SNI92 level to minimize the effects of measurements errors. 


\section{Appendix $3 \quad$ Additional results}

Table A5. Relative TFP levels before, during and after entry (or exit)

\begin{tabular}{|c|c|c|c|c|c|c|}
\hline \multirow{2}{*}{$\begin{array}{c}\text { Point of } \\
\text { Time }\end{array}$} & \multicolumn{6}{|c|}{ Firm type } \\
\hline & Never & Stoppers & Starters & $\begin{array}{l}\text { More } \\
\text { global }\end{array}$ & $\begin{array}{l}\text { Less } \\
\text { global }\end{array}$ & Switchers \\
\hline-2 & 0 & $\begin{array}{c}0.117 \\
(0.072)\end{array}$ & $\begin{array}{l}0.105^{*} \\
(0.046)\end{array}$ & $\begin{array}{l}0.089 * \\
(0.041)\end{array}$ & - & $\begin{array}{c}0.080 \\
(0.051)\end{array}$ \\
\hline-1 & $\begin{array}{l}-0.040 \\
(0.029)\end{array}$ & $\begin{array}{c}0.075 \\
(0.058)\end{array}$ & $\begin{array}{l}0.118^{*} \\
(0.048)\end{array}$ & $\begin{array}{c}0.078 \\
(0.049)\end{array}$ & $\begin{array}{c}0.084 \\
(0.049)\end{array}$ & $\begin{array}{c}0.057 \\
(0.054)\end{array}$ \\
\hline 0 & $\begin{array}{l}-0.043 \\
(0.042)\end{array}$ & $\begin{array}{c}0.063 \\
(0.066)\end{array}$ & $\begin{array}{l}0.120^{*} \\
(0.056)\end{array}$ & $\begin{array}{c}0.153^{*} \\
(0.056)\end{array}$ & $\begin{array}{l}0.158^{*} \\
(0.055)\end{array}$ & $\begin{array}{c}0.135 \\
(0.070)\end{array}$ \\
\hline 1 & $\begin{array}{l}-0.017 \\
(0.052)\end{array}$ & $\begin{array}{c}0.063 \\
(0.080)\end{array}$ & $\begin{array}{c}0.149 * \\
(0.065)\end{array}$ & $\begin{array}{c}0.191 * \\
(0.064)\end{array}$ & $\begin{array}{l}0.179 * \\
(0.064)\end{array}$ & $\begin{array}{l}0.172 * \\
(0.082)\end{array}$ \\
\hline 2 & $\begin{array}{c}-0.011 \\
(0.065)\end{array}$ & $\begin{array}{c}0.106 \\
(0.123)\end{array}$ & $\begin{array}{l}0.169 * \\
(0.072)\end{array}$ & $\begin{array}{l}0.214 * \\
(0.074)\end{array}$ & $\begin{array}{l}0.231 * \\
(0.076)\end{array}$ & $\begin{array}{l}0.179 * \\
(0.088)\end{array}$ \\
\hline
\end{tabular}

* indicates that the coefficient is significantly different from Never(-2). As a firm control we include log employment. Year and industry (SNI92 3-digit) dummies are added. Standard errors are corrected for dependency among observations. 